\title{
情報セキュリティ評価概諞
}

菅野泰子1

著者抄録 : 情報システムと情報通信網が重要な社会インフラとなり, 政治, 経済, 社会, 生活を支え ている現在, 情報セキュリティ対策は必要不可欠である。企業や情報システムの抱える脆（ぜい）弱 性(情報セキュリティにおける弱点)が, 最悪の場合, 企業の存続を劦かすほど巨大になる可能性は現 実のものとして存在しており, 経営者は, 自社の情報セキュリティにおける脅威と脆弱性とリスク を見極め, 適切なリスクマネジメントを行うことが不可欠である。そして, 導入され, 運用されて いる対策が有効であるかどうかは評価される必要がある。評価無くして, 対策の実効性は担保でき ない。セキュリティ対策における評価には,「ISMS適合性評価制度による認証」「情報セキュリティ 監査」「脆弱性検査（または脆弱性診断, 脆弱性監査)」「セキュリティ対策ベンチマーキング」など が挙げられる。また, セキュリティ製品やシステムを評価・認証する制度として「ITセキュリティ 評価及び認証制度」がある。このそれぞれについては, 膨大な規格群と研究報告書, 解説が公表さ れている。これらのキーワードに示される「情報セキュリティ評価」の全体像を, 各評価の違いを 明らかにしつつ, ベースとなる標準や規格等も紹介しながら，その概要を提示する。

キーワード : 情報セキュリティ監査, ISMS適合性評価制度, 脆弱性検査（または脆弱性診断, 脆弱 性監査），情報セキュリティ対策ベンチマーク，ITセキュリティ評価及び認証制度，情報セキュリ ティガバナンス，情報セキュリティマネジメントシステム, PDCAサイクル

\section{An introduction to information security evaluation}

\section{KANNO Yasuko'}

Author Abstract: We are now living in an age when information systems and networks are becoming a critical infrastructure, supporting government, economics, society and our life. Taking measures for information security is absolutely imperative. In the worst case, security vulnerability inherent in organizations and their information systems may actually become serious enough to threaten the continuity of business and our daily life. Therefore, it is essential for executives in organizations to assess the threats and vulnerability of the information system and apply the proper risk management strategies. In order to take effective measures against such a threat, appropriateness of applied control should be evaluated carefully. Without valid evaluation, effectiveness of countermeasures will never be guaranteed. ISMS conformity assessment scheme, information security audit, vulnerability test (i.e. vulnerability audit or vulnerability assessment), and information security benchmark are examples of assessment methods for IT security. Furthermore, we can point out other example of IT security evaluation and certification program to verify and certify security products or systems. Concerning each of these appraisal methods, we can find significant quantity of standards, guideline, technical reports, and documents. This paper will present a comprehensive vision of information security evaluation and assessment by distinguishing a difference among these various methods.

Key words: ISMS conformity assessment scheme, information security audit, vulnerability test (i.e. vulnerability audit or vulnerability assessment), information security benchmark, IT security evaluation and certification scheme, information security governance, information security management system, PDCA cycle

\footnotetext{
1 独立行政法人 情報処理推進機構（IPA）セキュリティセンター 研究員（テ113-6591 東京都文京区本駒込2-28-8 文京グ リーンコートセンターオフィス16階) E-mail: y-kanno@ipa.go.jp

${ }^{1}$ IT Security Center, Information-technology Promotion Agency, Japan (16F Center Office Bunkyo Green Court, 2-28-8 Honkomagome Bunkyo-ku, Tokyo, 113-6591)
} 


\section{1.はじめに}

仮に,「セキュリティ評価という言葉からイメー ジする事柄を列挙し，その全体像をわかりやすく 簡潔に説明しなさい」という課題が与えられたと する。「セキュリティ評価」という言葉から導き出 されるキーワードは実に多様である。例えば, 私 なら, 次のようなものを挙げてみる。

「情報セキュリティ監査」

「ISMS適合性評価制度」

「脆弱性検査（または脆弱性診断,

脆弱性監查) )」

「情報セキュリティ対策ベンチマーク」

「ITセキュリティ評価及び認証制度」

このそれぞれについては, 膨大な規格群と研究 報告書, 解説が公表されている。上のようなキー ワードに示される「情報セキュリテイ評価」の全 体像を, 限られた紙面の中で, 情報セキュリティ 評価について初めて聞く人にも, わかりやすく簡 潔に説明するのは，難題のように思われる。

しかし, 5W1H (Why, What, Who, Where, When) にブレークダウンして考える, つまり，これらの 「セキュリティ評価」について, それぞれ，評価の 目的（なぜ評価が必要か, 何のための評価か), 評 価対象（何を評価するのか）, 評価者（誰が評価す るのか), 評価時期（いつ評価するのか）, 評価基 準と評価手法（どの評価基準に従いどのように評 価するのか) を提示することによってその違いを 明らかにすることは, 可能であろう。

「情報セキュリティ監査」，「ISMS適合性評価制 度」,「脆弱性検査（または脆弱性診断, 脆弱性監 査)」,「情報セキュリティ対策ベンチマーク」は組 織的情報セキュリティ対策である, 情報セキュリ ティマネジメントを構築, 実装, 運用する際に, そ の実効性について評価する制度や手法であり，お よそ情報システムを導入し, 守るべき情報資産を 持つ組織であれば, ユーザ企業, 開発側企業のい ずれも問わず，自己のセキュリティ対策の評価の ために活用することができる。それに対し，「ITセ キュリティ評価及び認証制度」は, 開発側企業が 自社のセキュリティ製品やシステムの評価・認証 を受けるために用いることができる制度であり， ユーザにとっては, 必要な保証レベルに応じた安 全な製品を導入するための評価の基準となる。

本稿では,これらのセキュリテイ評価について, 自社のセキュリティ対策を評価する際に, どの評 価手法なり制度なりを用いたらよいのか, または,
どの評価の組み合わせが妥当なのかを判断する材 料を提示するため, 評価論や評価手法の詳細に立 ち八ることなく, 簡潔にその概要を提示すること にする。

\section{2. 情報セキュリティ対策における意識 の変遷}

「なぜ評価が必要か?」という問いの前に,「な ぜ情報セキュリティ対策が必要か?」という問い が存在する。「情報セキュリティ対策の必要性」に ついては,さまざまなメディアで論じられており， その必要性については,社会的コンセンサスになっ ていると思われるので，本稿では一般的な論点お よびセキュリティ対策における意識の変遷につい て言及するにとどめる。

情報セキュリティ対策が必要不可欠である社会 的背景としては, 情報システムと情報通信網が重 要な社会インフラとなり, 政治, 経済, 社会, 生 活を支えているという事実がある。企業活動にお けるIT依存度は急速な高まりを見せ, ITは国際競 争力を高める駆動力でもある。便利なシステムは, 反面, 脆（もろ）さも内包している。2005年6月に は, アメリカのクレジットカードの取引情報を処 理する会社で約 4,000 万枚分のクレジットカード情 報が不正アクセスにより流出したことが公表され た。漏えいしたカード情報は不正利用され, 日本 の顧客へも被害は波及した。また，この事件に便 乗したフィッシングメールが出回るなど, 被害額, 国際社会に与える影響の大きさは, まさに衝撃的 であった。

$2 \sim 3$ 年前の情報セキュリティ対策における目的 意識は, 自らがウイルスや不正アクセスの被害に 遭わないためという面が強かったが, 現在では, 法令遵守と企業の社会的責任 (CSR:Corporate Social Responsibility) の観点から, そして, 企業の適切な 危機管理の面からも, その必要性が取りざたされ ている。本年3月には, 経済産業省より「情報セキュ リティガバナンスのあり方に関する研究会 報告 書」が発表されたが, この報告書には, 「我が国で は, 法令遵守と企業の社会的責任の両面から, 企 業における情報セキュリティ対策が問われつつあ る」との記載がある。

同報告書が参照している, 米National Cyber Security Partnership (NCSP) のコーポレート・ガバ ナンス・タスクフォースが2004年4月に発表した 「Information Security Governance A CALL TO 
ACTION」には,「to make cyber security part of its corporate governance efforts」(サイバーセキュリティ を, コーポレート・ガバナンスへの取り組みの一 部と位置付ける），「The best way to strengthen US information security is to treat it as a corporate governance issue that requires the attention of Boards and CEOs」(米国の情報セキュリティを強化する最 も良い方法は, それをコーポレート・ガバナンス の取り組みとして行うことであり，それには経営 的配慮が必要）との記載もある。NCSPのレポート で提唱している情報セキュリティガバナンス構築 のための枠組みや, 推奨される行動は, 経済産業 省の報告書で提唱しているものと必ずしも同一で はないが,「情報セキュリティをコーポレートガバ ナンスの中に位置付ける」という基本的考え, ま たそのためには, 経営陣の気付きと積極的な関与 が必要であるとする点は類似している。なお, 経 済産業省の報告書では, 「情報セキュリティガバナ ンス」は「社会的責任にも配慮したコーポレート・ ガバナンスと, それを支えるメカニズムである内 部統制の仕組みを, 情報セキュリティの観点から 企業内に構築・運用すること」と説明されている。 社会の信頼と共感を得るためには, 情報セキュ リティ対策が必要であり, 同報告書には, CSR報 告書に, 情報セキュリティ対策の方針や実施状況 について記載し, 情報開示を行っていく事例が紹 介されているが, これなどは, 情報セキュリティ ガバナンスの取り組みの一例であろう。なお, 同 報告書の中では「情報セキュリティ報告書モデル」 として, 当該企業の取り組みが顧客や投資家など のステークホルダーから適正に評価されることを 目指すために, 企業の情報セキュリティの取り組 みの中でも社会的関心の高いものについて情報開 示するための基本的なモデルを提示している。企 業は,このモデルの中に示された記述項目の中か ら必要なものを選択し, 単独の情報セキュリティ 報告書として公表したり, CSR 報告書の一部に組 み込んで公表することができる。

\section{3. 情報セキュリティマネジメントシス テムにおける対策と評価}

セキュリティ対策を始める第一歩はリスクアセ スメントである。リスクアセスメントとは, リス ク分析からリスク評価までの一連のプロセスであ り, 自社にどのような情報資産があり, その情報 資産への脅威がどの程度高いか, 自社の脆弱性に
はどのようなものがあるかを分析し,セキュリティ 事故が起こった時の潜在的損害（リスク）を評価 する作業である。

企業や情報システムの抱える脆弱性(情報セキュ リティにおける弱点)が, 最悪の場合, 企業の存続 を劦かすほど巨大になる可能性は現実のものとし て存在している。経営者としては, 自社の情報セ キュリティにおける脅威と脆弱性とリスクを見極 め, 適切なリスクマネジメントを行うことが不可 欠である。そして, 適切なリスクマネジメントの ためには, 経営者を頂点とした組織的な取り組み が必要である。

情報セキュリティマネジメントシステム (Information Security Management System:ISMS) は, 組織的に情報セキュリティ対策を行うための管理 手法であり,Plan(計画)-Do(実施)-Check(点検·監査· 見直し)-Act(処置)というPDCAサイクルを繰り返す プロセスアプローチにより, 組織のセキュリティ 対策における目標達成レベルを継続的に維持改善 することを目指している。Plan(計画)は, セキュリ ティポリシーの策定に代表される, ISMSを確立す るための計画段階である。リスクアセスメントの 結果に従い, 守るべき情報資産を何から守るのか を決定し，導入すべき対策 (管理策) を取捨選択 する。計画段階で選択した対策を導入し運用する のは, Do(実施)にあたり, ISMSの監視および見直 しはCheck（点検・監査・見直し)にあたり, ISMS の維持および改善はAct(処置)にあたる。

管理策の選定にあたってよく参照されるのは, ISO/IEC 17799:2000がJIS化されたJIS X 5080:2002(情 報技術一情報セキュリティマネジメントの実践の ための規範）である。ちなみに, IPAセキュリティ センターでは, Web上にさまざまな情報セキュリ

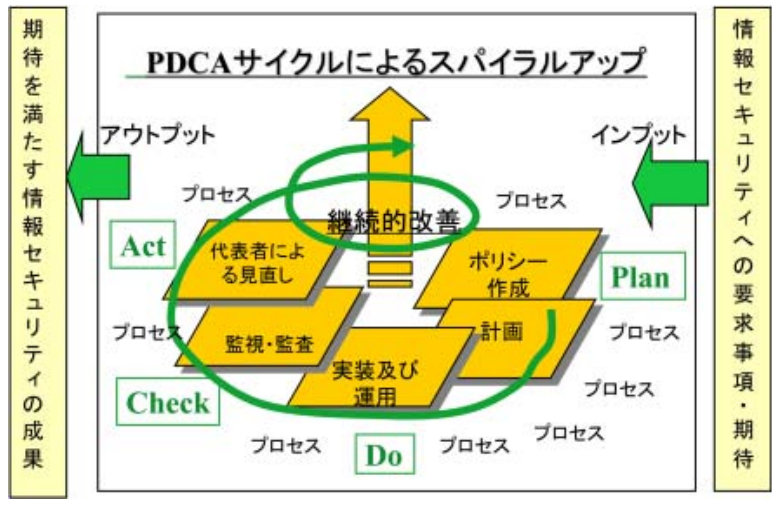

図1 PDCAモデルによるプロセスアプローチ （出典：財団法人日本情報処理開発協会） 
ティ対策実践情報を公開している。

さて, 導入され, 運用されているセキュリティ 対策が目的の達成（セキュリティレベルの維持向 上）のために, 有効であるか, 漏れは無いか, 隠 れた脆弱性が潜んでいないかなどは, 評価され, 確認される必要がある。そうしないと, せっかく 対策を行っても，その実効性が担保できないから である。冒頭で述べたように, 情報セキュリティ マネジメントシステムの枠組みの中で行われる評 価としては,「ISMS適合性評価制度による認証」「情 報セキュリティ監査」「脆弱性検査（または脆弱性 診断）」「セキュリティ対策ベンチマーキング」な どが挙げられる。それぞれがどのようなものなの かを概説してみる。

\section{1. 情報セキュリティ監査}

情報セキュリテイ監査制度は, 経済産業省主導 のもと, 2003年3月に運用開始された。情報セキュ リティ監査は, Plan(計画)-Do(実施)の段階を経て導 八されたセキュリティ対策が期待どおりに機能し ているかどうかを評価する作業である。構築され たISMSの実効性を担保するために, 専門知識を有 する独立の監査人によって行われる第三者評価で あり, ISMSにおけるマネジメントやコントロール が適切であることを保証する「保証型監査」と, 設 定した情報セキュリティレベルとの間にどのよう な差異があり, どのような是正措置を行えば良い のかを助言する ,「助言型監査」がある。監査を受 けるにあたっては, 助言型であるか, 保証型であ るか, あらかじめ設定されている必要がある。助 言型, 保証型は排他的ではなく, 一部分の保証と 助言の混合という形態も認められる。

監査の目的 : 情報セキュリティ監査を受ける組 織体において, 情報資産に対するリスクマネジメ ントが適切に実施されているかどうかを評価する。 監査を受ける範囲と深さに応じて, 助言を目的と するもの（助言型監査），保証を目的とするもの (保証型監査) がある。

監査の対象 : 情報セキュリティにかかわるリス クマネジメントまたはコントロールの実施状況を 対象とする。具体的に設定される監査目的と監査 対象は監査依頼者の要請に応じる。

監査の実施者: 独立かつ専門的知識を有する専 門家が監査を行う。監査対象より独立かつ中立で あれば, 内部監査人, 外部監査人のいずれでも良 い。外部監査人を選ぶためには, 経済産業省の情
報セキュリティ監査企業台帳を参照することもで きる。監査企業台帳への登録は自己申告制である (http://www.meti.go.jp/policy/netsecurity/is-kansa/)。

監査時期 : 1 年に1回などの割合で定期的に行う。 PDCAサイクル（図1）では, 監査の実施は, Check (点検·監査・見直し) にあたり, 監査の助言に従っ て改善を行うのはAct(処置)にあたる。監査に要す る期間は目的や対象の設定により異なるが, 監査 計画の立案から監査報告書の作成まで，おおむね 3か月から6か月ほどかかるようである。

準拠する基準 : 情報セキュリティ監査基準（監 査人の行動規範) と情報セキュリティ管理基準 (監 査人が用いる監査上の判断基準) がある。

(1)情報セキュリティ監査基準

監査業務上の遵守事項を規定する「一般基準」, 監査実施上の枠組みを規定する「実施基準」, 監査報告書について規定する「報告基準」よ り構成される。

(2)情報セキュリティ管理基準

JIS X 5080:2002（情報技術一情報セキュリティ マネジメントの実践のための規範）を元に策 定されている。130を超えるコントロール（管 理策) と, 900を超えるサブコントロールがあ る。後述する,「ISMS適合性評価制度」におい ても, ISMS認証基準（Ver.2.0）の詳細管理策 は,JIS X 5080:2002を基に作成されているため, 「情報セキュリティ監査」と「ISMS認証」にお ける判断の基準は整合性が取れている。

監査の実施手順: 監査実施のフレームワーク (図 2）を参照

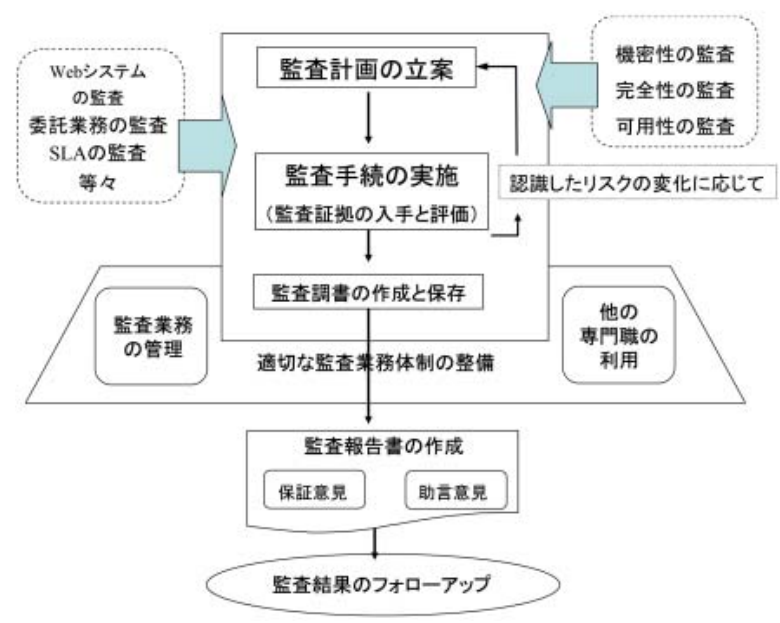

図2 監査実施のフレームワーク

（出典 : 情報セキュリティ監査基準） 


\subsection{ISMS適合性評価制度による認証}

「ISMS適合性評価制度」は，ISMS（情報セキュ リティマネジメントシステム）が基準にのっとり 適切に構築運用されていることを, 正式に認定さ れた審査登録機関と審査員が所与の判断基準によ り評価し, ISMS認証基準に適合していると認めら れた場合, 認証を付与し登録する制度である。こ の制度で用いられる基準は, 国際標準に準拠する かたちで制定されている。本制度は, 財団法人日 本情報処理開発協会 (JIPDEC) により運用されて いる。

制度の目的:国際的に整合性のとれた情報セキュ リティマネジメントに対する第三者適合性評価制 度であり, 国の情報セキュリティ全体の向上に貢 献するとともに, 諸外国からも信頼を得られる情 報セキュリティレベルを達成することを目的とし ている。

認証を受ける側の目的 : 組織として情報セキュ リティマネジメントが確立されていることを, 制 度の枠組みの中で評価・認証を受けることにより 確認する。また, 認証を取得することにより, 自 社の情報セキュリティ対策が認証取得レベルであ ることを体外的にアピールし, 企業価值を高める ことができる。

評価・認証の対象と範囲 : 組織の情報セキュリ ティマネジメントシステムを刘象とする。評価・ 認証を受けるマネジメントシステムの範囲は, 企 業全体でも, ひとつの事業部門でも, 複数の部門 にまたがってもよい。ただし，「その範囲がひとつ のマネジメントとして網羅的であり, 適用範囲の 境界線が明確で説明可能であること」(ISMS認証 基準)という条件がある。

評価・認証の実施者：ISMS審査登録機関認定基 準に基づき, 認定機関（JIPDEC/ISMS制度推進室） が評価・認定した審査登録機関が評価を行う。審
査登録機関は，現在 20 社ある (http://www.isms.jipdec. $\mathrm{jp} / \mathrm{st} / \mathrm{isr} / \mathrm{index} \cdot \mathrm{html})$ 。ISMS認証を希望する者は, こ れらの機関の中から自社の認証審査を行うところ を選定し, 認証の申請を行う。

認証取得までの期間 : 審査登録機関に認証の申 請を行ってから認証まで, 予備審査, 文書審査, 実 地審査を経る。認証取得までの期間は, 認証を申 請した組織がISMS構築のどの段階で申請をしたか に左右される。ISMS構築の最初の段階で申請した 場合は 1 年ほど, ISMS構築·運用をすでに行ってい る場合は4〜5か月程度かかるようである。

認証の有効期間 : 認証登録後3年間有効である。 認証登録されたら, 通常 1 年ごとに維持審査(サー ベイランス)が行われる。有効期間が切れる 3 年目 には, もう一度更新審査を受ける

準拠する評価基準 : ISMS認証基準。英国におけ るISMS 認証をするための規格であるBS7799-2 （Part2）に基づいて策定された。現在, BS7799-2は, 国際標準化の最終段階にあり，2005年度中には， ISO/IEC 27001 ISMS Requirementsとして規格化され る見込みである。また, ISMS認証基準Ver.2.0の詳 細管理策は, BS7799-1（Part1）が国際標準化され た，ISO/IEC 17799:2000に基づき策定されている。 なお, ISO/IEC 17799:2000は2002年にJIS X 5080とし てJIS化された。そのほか, ISMSユーザーズガイド, 法規適合性に関するISMSユーザーズガイドなど, この制度を支えるさまざまなガイドブックが JIPDECのホームページよりダウンロード可能であ る(http://www.isms.jipdec.jp/std/index.html)。現在, ISMSに関連する国際標準は新たな体系での標準化 が進んでおり, ISMS認証基準もそれら標準化動向 を踏まえて改定されていくことになる。

認証を受けるための要求事項 : ISMS認証基準の 「第 4 情報セキュリティマネジメントシステム」 「第5 経営者の責任」第6 マネジメントレビュー」

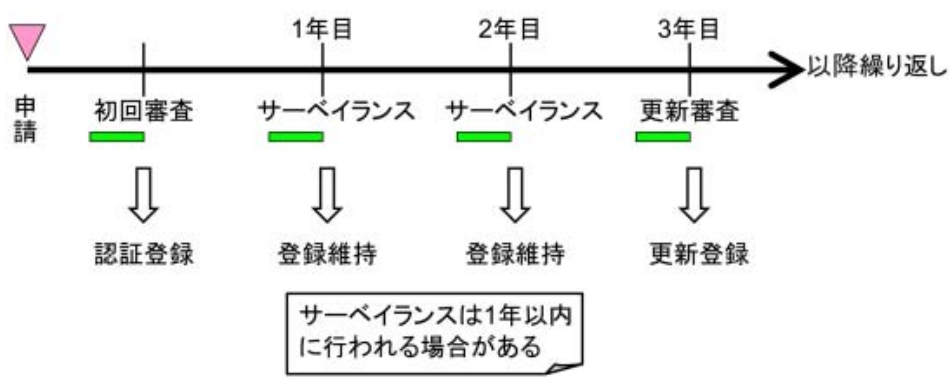

図3 認証登録, 登録維持, 更新登録 （出典：財団法人日本情報処理開発協会） 
「第7 改善」に記載の要求事項は, 認証を受ける ためには必須である。付属書の「詳細管理策」に 関しては, 除外は認められるが, 除外する場合, リ スクアセスメントの結果に基づき, 経営陣や責任 者が判断して正式に残留リスクの受容が決定され たことを示す証拠を,適用宣言書に残す必要がある。

ISMS認証取得事業者 : 2005年6月30日現在930社 ある(JIPDEC発表)。ISMS 認証書の発行数は, 国際 的に見ても日本が最多である（http://www.xisec. com/register.htm参照)。

このように見てくると, 情報セキュリティ監査 とISMS適合性評価には明らかな違いがある。監査 はPDCAサイクルではC(check), A(Act)にあたるが, ISMS適合性評価の認証を受けるには, 監査もしく はC(Check)の段階を経ていることが必須であり， PDCAサイクルを最低でも1回はまわしている必要 がある。また, 情報セキュリティ監査のうちでも 助言型監査は, ISMS適合性評価に比べてかなり自 由度の高いものである。例えば「脆弱性対策」や 「アクセス制御」などの技術的部分についてのみ監 査を受けることも可能である。これらの助言型監 査を積み上げて, 保証型監査を受けるレベルまで 組織的対策レベルを向上させることにより，ある 段階でISMS認証を取得することも考えられるため， 情報セキュリティ監査はISMS認証のすそ野を広げ るものという位置付けもなされている。

\section{3. 脆弱性検査（または脆弱性診断, 脆弱性監査)}

脆弱性という言葉が意味するところは広い。狭 義では, ソフトウエア製品やWebアプリケーショ
ン等のセキュリティ上問題のある箇所のことを言 い, 広義では, 弱いパスワードや設定ミス, 管理 上の不備なども含んだ広い意味でのセキュリティ 上の久陥ととらえられている。このような問題が あると, 攻撃の標的となりやすく, 攻撃により現 実の被害を被ることも多い。そこで, 脆弱性検査 を行い, 情報システムに潜む脆弱性を探し出し, 対策を行うことが必要となる。脆弱性検査では, 個々のシステムや運用状況, 実施状況に焦点を当 てて, 対策はきちんと行われているか, 潜在的な 危険は無いか, 設定に誤りは無いかなどを検査し, 不具合があれば改善する。脆弱性検査にはさまざ まな形がある。一般的な攻撃手法に基づいて, 擬 似的に攻撃を行う侵入テストに始まり, ソフトウ エア製品の脆弱性を対象とする場合は,脆弱性デー タベースをもとにネットワーク全体に脆弱性スキャ ンをかけてパッチの未適用状況などを洗い出す検 査がある。また, Webアプリケーション等の脆弱 性を対象とする場合は, Webアプリケーションに スキャンをかけて脆弱性を検査したり, Webアプ リケーションのソースコードをチェックし, ソー スコードから脆弱性を詳細に検査するものなどが ある。さらには, ネットワーク構成・運用方法・利 用形態・開発時期などさまざま観点からネットワー ク全体, もしくは組織全体の脆弱な部分を検査し, サーバの設定不備やアクセス制御設定の不備, 管 理運用上の不備等の脆弱な部分を総合的に洗い出 し, 解決策を示すという検査もある。

脆弱性検査は, PDCAサイクルではD(Do)および $\mathrm{C}$ (check)の段階における評価と考えることができ

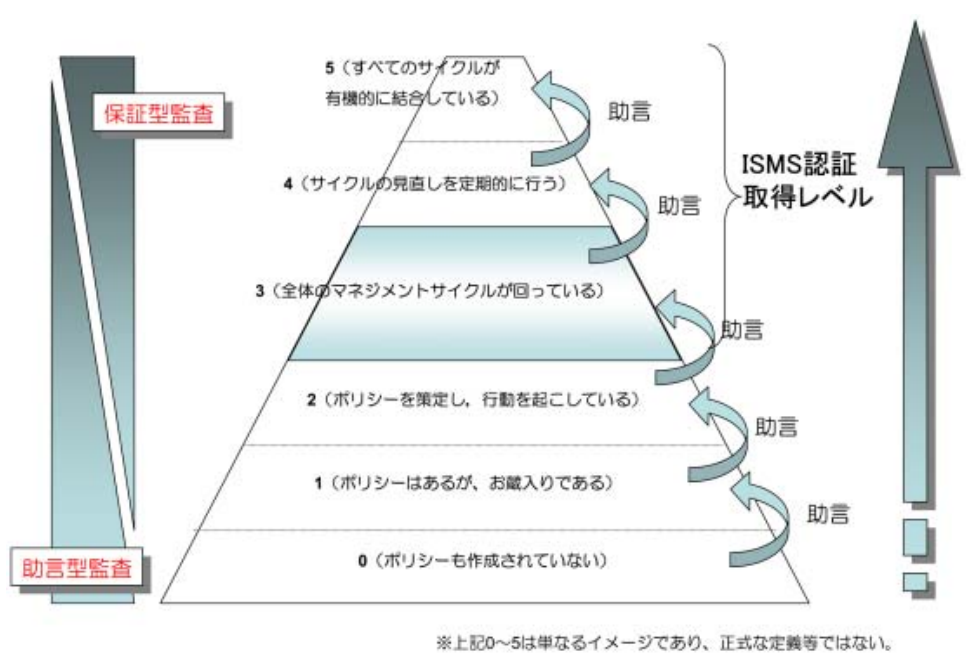

図4 情報セキュリティ監査とISMS関係のイメージ図 （出典 : 経済産業省「情報セキュリティ監査研究会報告書」） 
る。なお, 広義の脆弱性を対象とし, ネットワー クや組織の脆弱な部分を検査し, 解決策を示すよ うな検査は, 情報セキュリティ監査 (助言型監査) の一形態ととらえることもできる。

脆弱性に関して最近問題になっているのは,ッー ルではチェックしきれないWebアプリケーション の脆弱性に関する問題である。ソフトウエア製品 やWebアプリケーションに関して脆弱性対策や脆 弱性検査を行う場合には，使用している製品に見 つかった修正プログラムの適用と自社で使用して いるWebアプリケーションに存在する脆弱性の問 題は, 明確に分けて対策および検査をする必要が ある。脆弱性対策に関しては, IPAのWebサイトに さまざまな情報が掲載されているので参照された い。

Webアプリケーションの脆弱性を悪用した攻撃 の一例を紹介する。7月6日に, 中国人留学生 $(27$ 歳）が不正アクセス禁止法違反で逮捕された。容 疑は,「価格.com」を含む14社のWebサイトから，不 正アクセスにより50万件以上の個人情報を盗み, それをインターネット上で売りさばいていたとい うものである。不正アクセスに使われたのは, SQL インジェクション注1の脆弱性を攻撃する自動化ツー ルだった。このツールを使って，脆弱性を抱えた Webサイトを調べ出し, 簡単な操作をするだけで, データの保存されているサーバに侵入し, 情報を 盗み出したのであった。従来はSQLインジェクショ ンの脆弱性を攻撃するには,技術的能力が必要だっ たが，昨年秋頃から中国のサイトに，スキルが無 くても簡単に攻撃できるツールが公開され，その 後, この種のツールを使った攻撃が世間を騒がせ るようになった。この事件に限らず，脆弱性を悪 用した不正アクセスやウイルスによる攻撃の事例 は枚挙にいとまが無い。そして,さまざまな脆弱 性を攻撃するッールはインターネット上で無償ダ ウンロードが可能である。

以下に脆弱性検査における $5 \mathrm{~W} 1 \mathrm{H}$ をとめてみ る。

検査の目的：「脆弱性対策」に特化した検査であ り，脆弱性対策および脆弱性マネジメントが適切 に行われているかどうかを評価する。

検査対象：脆弱性検査を実施または依頼する組 織のニーズに応じて, 脆弱性検査を行う対象はさ まざまである。単体のサーバを対象にすることも あれば，ネットワーク全体のこともあり，組織全 体を対象とする場合もある。

検查の実施者 : 情報システム部門が行うことも
あれば，セキュリティベンダーに依頼することも ある。自己評価，他者評価のいずれも可能である。

評価時期 : 検査時期や検査に要する期間は, 検 査目的, 検查対象, 検査方法によりさまざまであ る。毎日行うもの, 1 週間や1か月に1回定期的に行 うもの, 1 年を通してスケジュールを決めて行うも のなど。新しい脆弱性が発見された時, システム を更新した時, 世の中を騒がすようなインシデン トが発生した時など, 状況に応じて脆弱性検査を 行うことは推奨される。

検査の基準: 公表されている脆弱性に対し,パッ チが適用されているかどうかを検査することは, 重要な検査項目である。それゆえ, 多くのベンダー の脆弱性情報をデータベースとして持ち, ネット ワーク上の多くのマシンに対しスキャンをかけて, パッチ未適応のマシンが無いかどうかを検査する ことが, 脆弱性検査の代表格のように考えられて いる。しかし, 脆弱性情報にとどまらず, 検査主 体が独自に作成した技術的対策基準や，各セキュ リティ機関から発表されている実践刘策情報など に照らし, 対策状況を評価する場合も少なくない。

検查方法 : 脆弱性検査ツールを使うもの, Web アプリケーションのコードチェック等の監査, あ る手順に応じてシステマティックに行うものなど さまざまである。脆弱性検査ツールにはNessusや SARA (Security Auditor's Research Assistant)などの ようにインターネット上から無償でダウンロード できるものもあるが, これらのツールを使いこな すには，それなりの知識とスキルが必要であるた め, セキュリティベンダーに依頼する向きも多い ようである。

\section{4. 情報セキュリティ対策ベンチマーク}

「情報セキュリティ対策ベンチマーク」は, 経済 産業省が本年3月に発表した「企業における情報セ キュリティガバナンスのあり方に関する研究会 報告書」の一部として公表された。情報セキュリ ティガバナンスとは,「社会的責任にも配慮した コーポレート・ガバナンスと, それを支えるメカ ニズムである内部統制の仕組みを, 情報セキュリ ティの観点から企業内に構築・運用すること」で あり，情報セキュリティ対策ベンチマークは，情 報セキュリティガバナンスを推進するための, 自 己評価用のツールと位置付けられている。

ベンチマークは, 一般に, 計測の基準となる指 標のことを言う。ベンチマーキングは, ある指標 （ベストプラクティス）を探し出し，それと比べる 
ことによって，自社のレベルを評価し，足りない 部分を改善していく経営改善の手法としても知ら れている。この自己評価と業務改善の手法を情報 セキュリティ対策に応用したのが, 「情報セキュリ ティ対策ベンチマーク」である。

なお,IPAのWeb上で,Webべースのセルフチェッ クサービスが公開されており, 各評価項目の質問 に答えていくと, トータルスコアが計算されて, 自社がどのレベルにあり, 望ましい水準とどの程 度のギャップがあり, どのような対策が不足かを チェックすることができる。

情報セキュリティガバナンス推進のためには, 経営陣の気付きと積極的な関与が不可欠であるの だが，自社のレベルが望ましいレベルとどの程度 のギャップがあり，どこまで対策をすれば良いか という基準が示されないと, 実際の行動には結び 付きにくい。「情報セキュリティ対策ベンチマー ク」は, 経営層が, セルフチェックを通じて自社 のレベル, 推奨される対策を理解し, 情報セキュ リティへの取り組みを活性化させるためのツール であり，特に，情報セキュリティ対策を実施して いない，あるいは簡易な対策しか行っていない中 堅・中小企業に使われることを想定している。ま た, 経営層向けに平易な言葉を使用するとともに, ガバナンスの観点から見た対策の取り組み方（成 熟度）を評価の基準としている。

以下に情報セキュリティ対策ベンチマークにお ける5W1Hをまとめてみる。

評価の目的：セルフチェックを通じて自社のレ ベルと推奨される対策を理解し,もって情報セキュ リティへの取り組みを活性化させるため。

評価対象:自社のセキュリティレベルの自己評価。

評価者（ツールの使用者）: 経営層の担当責任者 （情報セキュリティガバナンス推進という観点から すれば, 最もツールを使用してほしいのは, 経営 層であるという意味であり, 実務担当者が使うこ とも当然ありうる)。

評価時期：随時。PDCAサイクルではPlan(計画)Do(実施)-C(check)のそれぞれの段階で使用するこ とが可能。

評価基準 : 評価項目は,「セキュリティ対策」 25

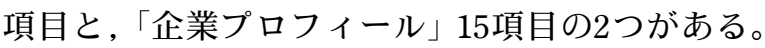
「企業プロフィール」から「社会的影響力」と「事 業構造上の脆弱性」を算出し,この2つの軸により， 「高水準のセキュリティレベルが要求される層」「相 応のセキュリティレベルが望まれる層」「情報セ キュリティ対策が喫緊の課題ではない層」の3つに
分けられる。対策の取り組み状況を把握するため の評価項目は,「セキュリティ対策」25項目である。 この25項目は, ISMS認証基準Ver.2.0の詳細管理策 をべースに作成されているが，役員クラスが利用 するとの想定のもと, 平易な言葉で記述され, 評 価項目の量も抑えられている。

評価方法 : 評価作業では, 各評価項目に関する 自社の取り組みの「成熟度」を確認する。成熟度 は，取り組みが「できていない」から「できてい る」まで，5段階に分けられる。具体的には, Web 上で質問に答えていくことで, 現在実行している 情報セキュリティ対策のレベルを把握し，その対 策が「望まれる水準」に達しているか否かを判定 できる。対策の取り組み状況25項目は各項目 5 点満 点, 総計 125 点満点で示され, この点数は, 5 段階 の成熟度に換算される。そして, 企業プロフィー ルにより判定される3つの層それぞれに対策の取り 組み状況の上位 $1 / 3$ の平均值と全体平均值が示され, 上位 $1 / 3$ の平均值が到達すべきセキュリティレベル として設定されている。

先に述べたように,「情報セキュリティ対策ベン チマーク」は, PDCAサイクルではPlan(計画)-Do( 実施)-C(点検)のそれぞれの段階での活用が可能で ある。自社の現在のレベル,望ましい水準とのギャッ プ，不足している対策がスコアとして示されるた め, Plan(計画)段階での活用は, 特に有効であると 考えられる。また, ベンチマークを繰り返し活用 することで, 徐々にレベルを上げていくことが可 能であるので, Do(実施)-C(点検)での活用も十分に 効果的である。

また, 対策の取り組み状況25項目は, ISMS認証 基準Ver.2.0の詳細管理策をべースに作成されてい

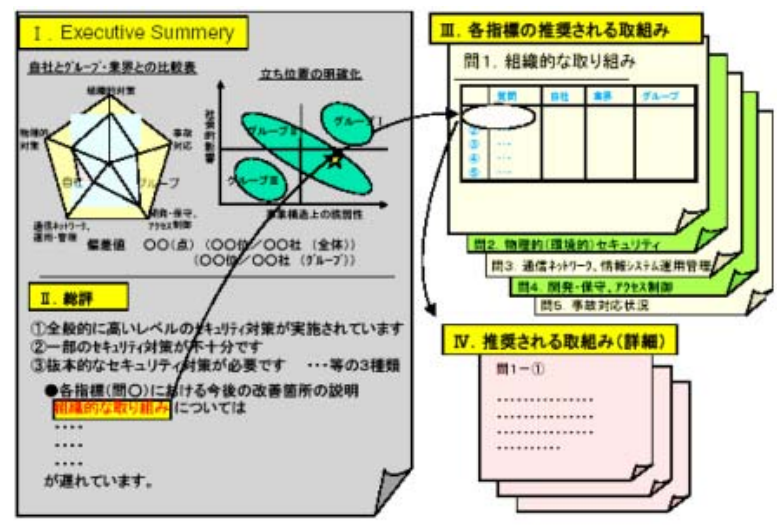

図5 セルフチェック結果のイメージ

（出典 :「企業における情報セキュリティガバナンスの あり方に関する研究会報告書」） 
るため, ISMS認証取得のためには, 準備段階とし て活用が可能である。

なお, 海外においても, 情報セキュリティ対策 における自己評価ツールは公表されている。情報 セキュリティガバナンス推進のために, 経営陣の 気付きと積極的な関与を促すという,「情報セキュ リティ対策ベンチマーク」と同様の目的で提供さ れているものとしては, 米National Cyber Security Partnership (NCSP) のコーポレート・ガバナンス. タスクフォースが2004年4月に発表した「Information Security Governance A CALL TO ACTION」の付属文 書「ISG ASSESSMENT TOOL」(ISG=Information Security Governance）が挙げられるが，これは，「情 報セキュリティ対策ベンチマーク」に比べると， より簡便な評価方法を採用している。

また，情報セキュリティマネジメント関連の標 準化を行っているISO/IEC JTC1 SC27 WG1では, ISMS Metrics and Measurements という規格が標準化 の緒に就いたと聞いた。これは, 情報システム部 門の責任者や担当者が, ISMS構築に際し導入され た個々の管理策の効果および効率を自己評価する ためのツールであり, そのための指標(Metrics)と 測定方法（Measurements）を詳細に規定したもの となるようである。

\section{4.「ITセキュリティ評価及び認証」に おける評価と認証}

「ITセキュリティ評価及び認証制度」は, IT製品・ 情報システムが, ITセキュリティの観点から適切 に設計され，その設計が漏れなく実装されている かどうかを, 国際標準ISO/IEC 15408にのっとって, 正式に認定された評価機関が評価し, 認証機関が 認証を付与する制度である。本制度は, 独立行政 法人 情報処理推進機構（IPA）により運用されて いる。

以下に本制度の概要をまとめた。

制度の目的: セキュアな基盤構築に資するため, IT関連製品 (ソフトウエア, ハードウエア, ファー ムウエア）および情報システムのセキュリティ機 能・品質を評価・認証することを目的としている。 これによりIT製品・情報システムのユーザは, 認 証製品を安心して利用できる。また, 政府調達の 際, 導入を検討する製品を共通の基準で比較し, 必要な保証レベルに応じた安全な製品や情報シス テムを導入できるようになる。

評価・認証を受ける側（開発者）の目的：メー カーは, 効果的なセキュリティ対策やセキュリティ 機能を設計することが可能となり, 国際的に広く 認められる安全な製品や情報システムを開発する ことができる。また, 認証を取得することにより,

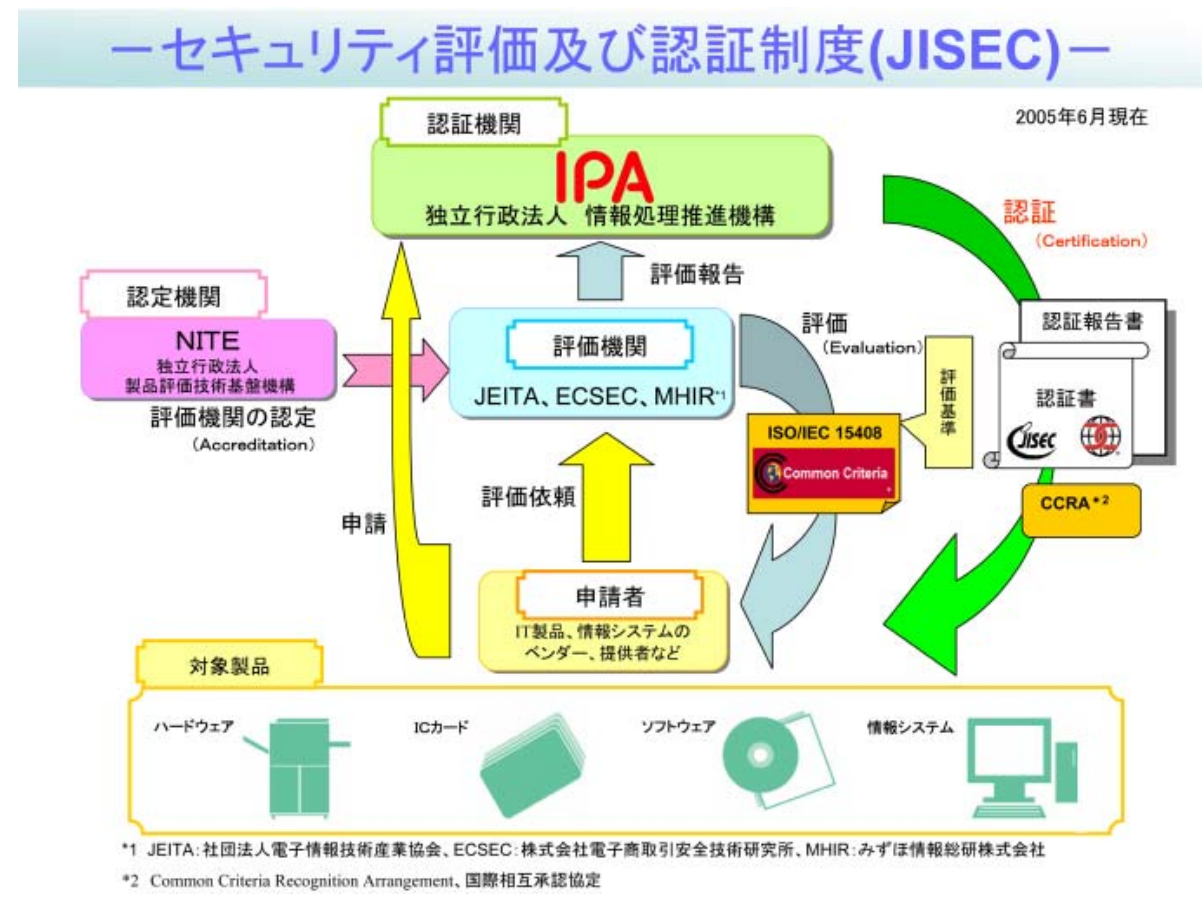

図6 セキュリティ評価及び認証制度 （独立行政法人 情報処理推進機構） 
安全性の高い製品や情報システムを提供している ことを利用者にアピールし，製品価值および企業 価值を高めることができる。

評価・認証の対象と対象範囲, 評価保証レベル： IT関連製品および情報システムを評価・認証の対 象とする。各国の評価，認証済みのIT製品の事例 としては, OS, DBMS, ファイアウォール, ルー タ, ICカード, ICカードリーダ, PKI製品などがあ る。評価を行う範囲は明確に定める必要があり, これを評価対象（TOE：Target Of Evaluation）と呼 ぶ。TOEに応じて評価保証レベル (EAL：Evaluation Assurance Level）は定まる。

保証継続: 認証を取得したIT製品やシステムが, バージョンアップをした場合, 通常は再評価を受 ける必要があるが, セキュリティ機能に影響がな いバージョンアップの場合には「保証継続」の仕 組みが用意されている。「保証継続」においては, 評価機関が実施する評価は行われず，認証機関に 影響分析報告書を提出し, 検証を受けることによ り，認証製品であるという保証が継続される。

ST (Security Target : セキュリティターゲット) 確認：日本では, EALに応じた検査のほかに, ST の評価のみを実施する「ST確認」という評価も選 択肢として用意している。日本独自の制度である が, STを作成するためには, 環境条件, 脅威およ びセキュリティ対策等を系統的に検討する必要が
あるため, STが正しく書かれているかどうかを評 価するだけでも重要な意味がある。

評価・認証の実施者: 本制度の運用に関しては, 評価を行う評価機関，評価機関を認定する認定機 関, 認証書を発行する認証機関の3つの機関が関係 する。

・評価機関：評価申請者からの依頼により, 評 価対象となる製品, 情報システムについて, 評 価を行う中立的な第三者機関。評価の結果と して, 評価報告書を作成する。2005年7月現在, 3 社の評価機関がある（http://www.ipa.go.jp/ security/jisec/eval-list.html)。

・認定機関 : 評価機関が評価する能力を有する かどうかを審査し, 認定する機関。独立行政 法人 製品評価技術基盤機構 (NITE) の中に 認定機関が設置されている。

·認証機関 : 評価機関によって行われた評価結 果を検証し, ISO/IEC 15408に基づいて正しく 評価が行われたことを確認し, 問題が無けれ ば，認証書を発行する機関。独立行政法人 情報処理推進機構（IPA）の中に認証機関が設 置されている。

認証取得までの期間：評価対象の規模や評価保 証レベル $(\mathrm{EAL})$ にって異なるため一概には言えな いが, EAL2の場合で最短で3〜4か月, EAL4の場 合，6か月以上かかることもある。「保証継続」の

表1＼cjkstart評価保証レベル（EAL: Evaluation Assurance Level）

\begin{tabular}{|c|c|c|}
\hline $\begin{array}{c}\text { 評価保証 } \\
\text { レベル }\end{array}$ & 名 称 & 評価概要 \\
\hline EAL7 & Formally verified designed and tested & $\begin{array}{l}\text { サブシステムレベルまでの設計が形式的表現, 開発者 } \\
\text { による分析・テストのすべてを評価者が再確認 }\end{array}$ \\
\hline EAL6 & Semiformally verified designed and tested & $\begin{array}{l}\text { モジュールレベルまでの設計が準形式的表現, 非常に } \\
\text { 高度の攻撃に対抗 }\end{array}$ \\
\hline EAL5 & Semiformally designed and tested & $\begin{array}{l}\text { 実装表現レベルのセキュリティ機能をすべて確認, サ } \\
\text { ブシステムレベルまでの設計が準形式的表現, 隐れ } \\
\text { チャネル分析, 高度の攻撃に対抗 }\end{array}$ \\
\hline EAL4 & $\begin{array}{l}\text { Methodically designed, tested, and } \\
\text { reviewed }\end{array}$ & $\begin{array}{l}\text { モジュールレベルまで確認, 実装表現レベル（最も具 } \\
\text { 体的レベルの設計：例えばソースコードレベル）の部 } \\
\text { 分的確認, 普通程度の攻撃に対抗 }\end{array}$ \\
\hline EAL3 & Methodically tested and check & $\begin{array}{l}\text { サブシステムレベルまでの開発者テスト結果の確認, } \\
\text { 構成管理システム使用の確認, 開発者環境の確認, 開 } \\
\text { 発者による誤使用分析 }\end{array}$ \\
\hline EAL2 & Structurally tested & $\begin{array}{l}\text { サブシステムレベルまでセキュリティ機能設計の確 } \\
\text { 認, 構成管理の確認, 開発者による機能強度, 脆弱性 } \\
\text { 分析, 評価者による侵入テスト }\end{array}$ \\
\hline EAL1 & Functionally Tested & $\begin{array}{l}\text { セキュリティ機能仕様, マニュアルの確認, 評価者に } \\
\text { よるテスト }\end{array}$ \\
\hline
\end{tabular}

注 : EALは情報セキュリティの実現度を示すものであってセキュリティ強度を示すものではない。 
場合, おおむね 1 か月程度で継続の認証を受けるこ とができる。

評価・認証を受ける手順: (1) ST等の評価用資料 の準備 $\rightarrow(2)$ 評価機関への評価依頼 $\rightarrow(3)$ 評価機関と の契約 $\rightarrow(4)$ 認証機関への認証申請 $\rightarrow(5)$ 評価機関に よる評価実施 $\rightarrow(6)$ 評価機関による評価報告書の作 成 $\rightarrow(7)$ 認証機関による認証の順に進む。

準拠する評価基準: 準拠する国際規格は, 1999 年6月にISO規格となった「ISO/IEC 15408 情報技術 セキュリティ評価基準」である。この規格は, 2000 年7月にJIS X 5070 としてJIS化されている。ISO/IEC 15408策定のもとになったのは,Common Criteria (コ モンクライテリア：CCと略す）と呼ばれる共通基 準である。CCは, 米国のTCSEC (Trusted Computer Systems Evaluation Criteria), 欧州のITSEC (Information Technology Security Evaluation Criteria)，などの既存のセキュリティ評価基準を持 つ欧米6か国（カナダ, フランス, ドイツ, イギリ ス,アメリカ, オランダ)で構成されたCCプロジェ クトによって開発された共通の評価基準である。 ISO/IEC 15408:1999 とCC Version 2.1は同等として扱 われている。評価手法は, CEM: Common Evaluation Methodologyと呼ばれている。

評価内容と評価保証レベル：評価保証レベル (EAL : Evaluation Assurance Level) は, TOEで扱う 保護資産の機密性, セキュリティ機能の脅威への 対抗性, 動作の信頼性等に応じて決定される。評 価機関は,このEALに応じた検査を行う。EALは, マニュアルだけに基づくテストによって確認する レベル（EAL1）から, 該当箅所のソースコードを みて確認するレベル（EAL4），さらには形式的記 述言語によって正当性が証明される開発を要求す るレベル（EAL7）までの7レベルが規定されてい る。これらのレベルに応じて開発環境, 開発管理 および開発文書等の評価内容が異なる。TOEは, 開発者が決める場合もあれば, 調達者・顧客が指 定する場合もある。開発者は, 評価対象となる製 品のTOEの特徵に合わせて, セキュリティに関す る設計仕様書であるSTを作成する。(利用者が評価 を要求する場合は, 利用者側のセキュリティ要求 仕様にあたるプロテクションプロファイル（PP : Protection Profile) でセキュリティに関する仕様を 宣言することもできる)。評価は, STの評価から始 まり, 次にSTに書かれている機能が製品／システ ムに確実に実装されているかどうかを, EALのレ ベルに応じて, 機能設計書やソースコード, テス 卜仕様書, マニュアル等, などさまざまな文書を
検査することにより実施する。

CC認証製品, ST確認製品: 2005年7月11日現在, CC認証製品は 30 , ST確認製品は 24 ある。(http:// www.ipa.go.jp/security/jisec/index.html 参照)。

\section{CCRA : 国際的な情報セキュリティ相互承認協 定制度}

CCRA (Common Criteria Recognition Arrangement) CCに基づいたセキュリティ評価・認証の相互承認 に関する国際的な相互承認協定。CCに基づいて評 価・認証されたIT製品の認証書は, 協定に合意し た国どうしでも相互に通用するという, 国際的な 相互承認協定の枠組みであり, 認証書発行国 (CAP: Certificate authorizing participants）および認証受入 れ国 (CCP: Certificate consuming participants) の2種 類のメンバーで構成されている。この枠組みには, CAPが8 か国CCPが13か国, 計21か国が加盟してお り, 日本は, CAPとして2003年10月にCCRAに加盟 している。

参考：6th ICCC 2005 in Tokyo（ICCC 2005） <http://www.ipa.go.jp/event/iccc2005/index.html>

ICCC (International Common Criteria Conference) は, 年1回CCRA加盟国において開催する本制度の 普及·促進を目的とした国際会議である。第6回と なる今年は, わが国において初の「ICCC」が2005 年9月28日(水) 29日(木)の 2 日間にわたり開催され る。この会議には, IT製品やシステムのセキュリ ティ評価に関連する者が一堂に会し, Common Criteriaにかかわる新規格の内容, 最新の情報セキュ リティ技術, 情報処理にかかわる妿威や脆弱性, セキュリティ評価の普及啓発などについて意見交 換や有益な情報の共有が行われる。

\section{5. おわりに}

評価というのはセンシティブな作業である。評 価されるほうも, 評価するほうも, 評価の正確さ, 公平さ, 品質, 信頼性をできるかぎり向上させた いと願うものである。それゆえ，特に評価·認証 という制度となった場合, 緻（ち）密に枠組みや 手順, 評価手法が定められ, 多くの標準や規格に 準拠して評価が行われる。ITセキュリティ評価及 び認証における評価と認証の項で, 準拠する国際 標準として, ISO/IEC 15408を挙げたが, 実は, 準 拠する規格や標準はこれだけではない。例えば, 認証機関(Certification Body)が評価結果の検証から 
認証書の発行を行う際に準拠すべき基準を定めた ものに, 「ISO/IEC Guide 65: General requirements for bodies operating product certification systems $\lrcorner$ があり, 認定機関(Accreditation Body)が評価機関の審査, 認 定，管理を行うにあたって準拠すべき基準を定め たものに,「ISO/IEC 17011: Conformity assessmentGeneral requirements for accreditation bodies accrediting conformity assessment bodies」があり, 評 価機関が準拠すべき標準に「ISO/IEC 17025: General requirements for the competence of testing and calibration laboratories」がある。このようにして評 価の品質や制度の信頼性を高めているのである。

しかしまた，セキュリティをめぐる環境はダイ ナミックに動いていることも忘れてはならない。

例えば, 脆弱性検査で, 対策は良好に行われて おり問題無し，という結果が出たとする。ところ が, 翌日, 新しい脆弱性が発見されたり, ネット
ワークに新しいサーバが設置されたりするだけで セキュリティ環境は変化するものである。これは, 本稿で紹介した他のセキュリティ評価に関しても, 程度の差や環境変化の状況は違っても, 大なり小 なり当てはまる事実である。そこで, どの評価に おいても, 定期的な再評価の枠組みが定められて いる。

セキュリティ対策にも, セキュリティ評価にも 終わりは無い。

\section{本文の注}

注1) SQL サーバに SQ インジェクションの脆弱性がある と, Web上の入カフォームからSQLコマンド（デー タベースへの命令) を入力することで,データベー ス内の情報の閲覧, 更新, 削除などができ, 結果 としてサーバ内ファイルの漏えいや改ざんなどの 被害を受けてしまう。

\section{参考文献}

1. 情報セキュリティガバナンス関連

1）経済産業省。“報道発表：企業における情報セキュ リティガバナンスのあり方に関する研究会報告書 の取りまとめ·公表について”. (オンライン), 入手 先<http://www.meti.go.jp/press/20050331004/ 20050331004.html >, (参照2005-07-13).

2）経済産業省. “白書・報告書：企業における情報セ キュリティガバナンスのあり方に関する研究会報 告書”. (オンライン), 入手先 < http://www.meti.go.jp/ report/data/g50331dj.html>, (参照2005-07-13).

3) The Corporate Governance Task Force of the National Cyber Security Partnership (NCSP). "Information Security Governance A CALL TO ACTION(Report April 2004)”. (online), available from $<$ http://www.cyberpartnership.org/ InfoSecGov4_04.pdf>, (accessed 2005-07-13).

4) The Corporate Governance Task Force of the National Cyber Security Partnership (NCSP). "Corporate Governance Task force" (online), available from < http://www.cyberpartnership.org/ init-governance.html >, (accessed 2005-07-13).

2. 情報セキュリティマネジメントシステム /ISMS 適合 性評価制度関連

1）財団法人 日本情報処理開発協会. “ISMS適合性評 価制度”。(オンライン), 入手先 < http://www.isms. jipdec.jp/>, (accessed 2005-07-13).

2）財団法人 日本情報処理開発協会. “ISMS認証基準
(Ver.2.0)” . (オンライン), 入手先 < http://www.isms. jipdec.jp/doc/JIP-ISMS100-20.pdf>, (accessed 200507-13).

3）財団法人 日本情報処理開発協会. “ISMSユーザー ズガイドーISMS認証基準(Ver.2.)刘応一”。(オンラ イン), 入手先 <http://www.isms.jipdec.jp/doc/uguide/ ugall.pdf $>$, (accessed 2005-07-13).

4）財団法人日本情報処理開発協会. “ISMSユーザーズ ガイドーリスクマネジメント編”. (オンライン), 入 手先 <http://www.isms.jipdec.jp/doc/JIP-ISMS11311.pdf $>$, (accessed 2005-07-13).

5） 中尾康二; 平野芳行; 水本政弘; 吉田健一郎. JIS X 5080:2002(ISO/IEC 17799:2000) 情報セキュリティ マネジメントガイド.東京, 財団法人日本規格協会, 2002, 288p.

6) 規格・標準

ISO/IEC 17799:2000: Information technology - Code of practice for information security management.

JIS X 5080:2002: 情報技術一情報セキュリティマネ ジメントの実践のための規範.

BS7799-2: Information security management systems - Specification with guidance for use.

7) ISMS International User Group. "International ISMS Register". (online), available from $<\mathrm{http}: / /$ www.xisec.com/register.htm>, (accessed 2005-0713). 


\section{3. 情報セキュリティ監査・脆弱性検査関連}

1）経済産業省.“情報セキュリティに関する政策, 緊急 情報 : 情報セキュリティ監査制度”。(オンライン), 入手先 $<$ http://www.meti.go.jp/policy/netsecurity/ audit.htm >, (参照2005-07-13).

2) 特定非営利活動法人 日本セキュリティ監査協会 ホームページ. (オンライン), 入手先 < http://www. jasa.jp/index.html>, (参照2005-07-13).

3) 特定非営利活動法人 日本セキュリティ監査協会. “情報セキュリティ監査制度利用促進等事業 実施報 告書 第3編 調査研究部会”。情報セキュリティ監査 を取り巻く国内・海外の状況に関する調査. (オン ライン), 入手先 $<$ http://www.jasa.jp/about/pdf2004/ rep0403.pdf >, (参照2005-07-13).

2) ティーエムエス編；日本システム監査人協会監修. システム監査・情報セキュリティ監査ハンドブッ ク：IT実務ハンドブックシリーズ. 東京, 秀和シス テム, 2004, 1165p.

3) Chris McNab.(鍋島公章監訳; ネットワークバリュー コンポネンツ訳) 実践ネットワークセキュリティ監 査一リスク評価と危機管理. 東京, オライリー・ジャ パン, 2005, 488p.

4）独立行政法人 情報処理推進機構. “脆弱性関連情報 の取扱い” (オンライン), 入手先 $<\mathrm{http}: / / \mathrm{www} . i p a$. go.jp/security/vuln/index.html>, (参照2005-07-13).

5）独立行政法人 情報処理推進機構. “ウェブサイトの セキュリティ対策の再確認を〜脆弱性対策の チェックポイント〜 (オンライン), 入手先 < http:/ /www.ipa.go.jp/security/vuln/20050623_websecurity. html>, (参照2005-07-13).

6）独立行政法人 情報処理推進機構. “消費者向け電子 商取引サイトの運用における注意点” (オンライン), 入手先 $<$ http://www.ipa.go.jp/security/vuln/ 20050304_ec_security.html>, (参照2005-07-13).

4. 情報セキュリティ対策ベンチマーク／自己評価ツー ル関連

1）経済産業省. “参考資料1：情報セキュリティ対策べ ンチマーク”。企業における情報セキュリティガバ ナンスのあり方に関する研究会 報告書. (オンライ ン), 入手先 <http://www.meti.go.jp/report/ downloadfiles/g50331d01j.pdf>, (参照2005-07-13).

2) The Corporate Governance Task Force of the National Cyber Security Partnership (NCSP). “APPENDIX D: ISG ASSESSMENT TOOL". Information Security Governance A CALL TO
ACTION (Report April 2004). p.27-34. (online), available from < http://www.cyberpartnership.org/ InfoSecGov4_04.pdf, (accessed 2005-07-13).

3) NIST SP 800-26: Security Self-Assessment Guide for Information Technology Systems. (online), available from http://csrc.nist.gov/publications/nistpubs/800-26/ sp800-26.pdf >, (accessed 2005-07-13).

4) NIST SP 800-55: Security Metrics Guide for Information Technology Systems (online), available from < http://csrc.nist.gov/publications/nistpubs/80055/sp800-55.pdf>, (accessed 2005-07-13).

5. ITセキュリティ評価及び認証における評価と認証関連

1）独立行政法人 情報処理推進機構. “ITセキュリティ 評価及び認証制度” (オンライン), 入手先 < http:// www.ipa.go.jp/security/jisec/index.html>, (参照200507-13).

2）独立行政法人 情報処理推進機構. “ISO/IEC 15408 入 門” (オンライン), 入手先 $<$ http://www.ipa.go.jp/ security/jisec/about_cc.html>, (参照2005-07-13).

3)「IT セキュリティ評価及び認証制度」に関する参考 資料および規格等の日本語訳

独立行政法人 情報処理推進機構. “セキュリティ評 価·認証”(オンライン), 入手先 $<$ http://www.ipa.go.jp /security/jisec/apdx0504.html>, (参照2005-07-13).

4) 田㴊治樹. 国際セキュリティ標準 ISO/IEC15408 入 門. 東京, オーム社, 2001, 320p.

5) 規格・標準

Common Criteria for Information Technology Security Evaluation (1999/8Ver.2.1)

ISO/IEC Guide 65 : General requirements for bodies operating product certification systems

ISO/IEC 17011: Conformity assessment-General requirements for accreditation bodies accrediting conformity assessment bodies

ISO/IEC 17025:1999 : General requirements for the competence of testing and calibration laboratories.

6. その他

1）独立行政法人 情報処理推進機構. “読者層別：情報 セキュリテイ対策 実践情報”.(オンライン), 入手先 $<$ http://www.ipa.go.jp/security/awareness/ awareness.html>, (参照2005-07-13).

2）独立行政法人 情報処理推進機構. “コンピュータ. セキュリティ〜2004年の傾向と今後の対策〜”. (才 ンライン), 入手先 < http://www.ipa.go.jp/security/ vuln/20050331_trend2004.html>, (参照2005-07-13). 